\title{
KATEGORISASI KEJAHATAN AGRESI ATAS TINDAKAN PENGGUNAAN KEKERASAN NEGARA PERANCIS PADA KONFLIK REPUBLIK MALI DALAM HUKUM PIDANA INTERNASIONAL
}

\author{
Nadia Maulida Zuhra \\ Program Studi Magister Ilmu Hukum Universitas Padjadjaran \\ Jl. Banda No. 42, Citarum, Kec. Bandung Wetan, Bandung, Jawa Barat (40115) \\ Email : nadiamaulidazuhra@gmail.com
}

\begin{abstract}
International law has set any dispute resolution mechanisms between countries in the world that require peaceful means as the main approach. However, if a peaceful settlement of a dispute is not achieved, violence can also be used or acts of use of force against the country concerned, but it is limited to certain reasons with the legitimacy of the UN Security Council. The illustrated about the act of use of force is French on conflict of the Republic of Mali which caused 5 (five) civilians including children were death, so that these actions can be categorized as crimes of aggression. Therefore, the benchmarks for limitative acquisition of the use of force in question are crucial enough for the consideration of the state in taking intervention action. This study aims to examine the position of the use of force action of French against the Republic of Mali as crime of aggression and the legal consequences of an aggression offender country.
\end{abstract}

Keywords; State responsibility, The crime of aggression, Use of force action

\begin{abstract}
Abstrak
Hukum internasional telah mengatur sejumlah mekanisme penyelesaian sengketa antar negara di dunia yang mengharuskan cara-cara damai sebagai pendekatan utama. Namun dalam hal penyelesaian sengketa secara damai tidak tercapai maka cara-cara kekerasan atau tindakan use of force terhadap negara yang bersangkutan dapat digunakan, akan tetapi bersifat terbatas hanya untuk alasan tertentu atas legitimasi Dewan Keamanaan PBB. Hal tersebut tergambarkan pada tindakan use of force Negara Perancis pada Konflik Republik Mali yang menyebabkan 5 (lima) warga sipil termasuk anak-anak diantaranya tewas dan diklaim sebagai bagian dari kategorisasi kejahatan agresi. Oleh karena itu, tolak ukur pembolehan limitatif akan penggunaan kekerasan yang dimaksud menjadi hal yang cukup krusial dalam pertimbangan suatu negara atas pengambilan keputusan suatu tindakan intervensi. Penelitian ini bertujuan untuk menganalisa kedudukan tindakan use of force yang dilakukan oleh Negara Perancis terhadap Republik Mali sebagai suatu kejahatan agresi dan akibat hukum terhadap negara pelaku kejahatan agresi.
\end{abstract}

Kata Kunci; Kejahatan agresi, Tanggungjawab negara, Tindakan use of force 


\section{PENDAHULUAN}

Hubungan internasional antar negara di dunia telah membentuk sejumlah pola interaksi internasional ke arah yang lebih positif. Pola interaksi internasional sebagaimana dimaksud dapat berbentuk kerjasama, persaingan atau konflik. ${ }^{1}$ Kerjasama secara bilateral maupun multilateral dalam hal ini memberikan jaminan terhadap kepentingan para pihak yang menjadikan hubungan antar negara menjadi semakin pesat perkembangannya. Akan tetapi, seiring dengan pesatnya perkembangan hubungan yang ada, bentuk sengketa antar negara di dunia juga menjadi semakin kompleks. ${ }^{2}$

Pada dasarnya perbedaan yang menimbulkan sengketa antar negara dapat diselesaikan dengan menggunakan cara-cara damai sebagai metode penyelesaian, akan tetapi ada kalanya penyelesaian sengketa sebagaimana dimaksud dapat berakhir dengan cara kekerasan. ${ }^{3}$ Hukum internasional menjamin setiap negara memiliki kedaulatan untuk mengurus urusan rumah tangganya sendiri. Prinsip kedaulatan tersebut tidak memperkenankan negara lain untuk melakukan campur tangan atas setiap permasalahan (baik urusan internal maupun eksternal) negara lainnya. ${ }^{4}$ Prinsip ini sudah diatur dengan jelas pada Pasal 2 ayat (4) Piagam Perserikatan Bangsa Bangsa yang selanjutnya disebut dengan Piagam PBB yang pada pokoknya menyatakan bahwa setiap negara anggota PBB wajib menjauhkan diri untuk menggunakan kekerasan (use of force) terhadap integritas wilayah atau kemerdekaan politik suatu negara lain atau dengan cara apapun yang bertentangan dengan tujuan PBB. Namun, pengecualian terhadap situasi-situasi tertentu menjadikan pembolehan terhadap tindakan penggunaan kekerasan sebagaimana dimaksud dapat diupayakan, seperti halnya apabila bertujuan untuk membela diri dari serangan yang terjadi di wilayah suatu negara (mengingat sifat alami manusia berupa respond membela diri saat mengalami serangan atau ancaman yang ditujukan terhadapnya). ${ }^{5}$

\footnotetext{
${ }^{1}$ Universitas Negeri Malang, 'Aktor Non-Negara Dalam Hubungan Internasional', 5.

2 Y.M. Perwita, A.A.B. \& Yani, Pengantar Ilmu Hubungan Internasional (Bandung: Rosda, 2006).

${ }^{3}$ Sefriani, Hukum Internasional (Edisi Pertama) (Jakarta: Rajawali Pers, 2010).

4 Jawahir Thontowi dan Pranoto Iskandar, Hukum Internasional Kontemporer (Bandung: PT. Refika Aditama, 2006).

${ }^{5}$ Alfandrio Christian Putra Makalew, 'Kedudukan Pre-Emptive Strike (Serangan Pendahuluan) Dalam Hukum Internasional', Jurnal Lex Et Societatis, Vol. VII N.Mei 2019, 13.
} 
Tindakan penggunaan kekerasan (use of force) yang baru beberapa waktu lalu terjadi salah satunya dapat dilihat pada tindakan Perancis dalam kudeta militer yang terjadi di Republik Mali tahun 2012. Pasukan Perancis mulai membangun kekuatannya di wilayah Mali setelah sebelumnya menginvasi Republik Mali dengan alasan bahwa tujuan utama mereka adalah untuk merebut kembali negara bekas jajahannya tersebut dari tangan pemberontak atas serangkaian pelanggaran HAM yang dilakukan selama kudeta militer berlangsung.

Rencana intervensi Negara Perancis awalnya disepakati oleh Masyarakat Ekonomi Negara Afrika Barat (ECOWAS). Namun, Perancis dalam mengambil inisiatif untuk menyerang Republik Mali dilakukan tanpa legitimasi Dewan Keamanan PBB. Bahkan, Sekjen PBB mengeluarkan dukungan justru setelah Perancis melakukan serangan.

Pada dasarnya itikad baik Negara Perancis bertujuan untuk membantu Republik Mali atas konflik yang terjadi merupakan hal yang dibenarkan dalam hukum Internasional, akan tetapi fakta bahwa adanya korban jiwa yang timbul atas tindakan intervensi yang dilakukan oleh Perancis pada tindakan penggunaan kekerasan yang dilakukan olehnya dapat digolongkan sebagai bagian dari kejahatan agresi. ${ }^{6}$ Badan Amnesti Internasional telah secara resmi mengumumkan adanya korban jiwa sebanyak 5 (lima) warga sipil termasuk 3 (tiga) anak diantaranya tewas sebagai akibat dari serangan udara yang dilakukan Perancis untuk merebut wilayah Utara Mali yang dikuasai oleh pemberontak. Hukum internasional telah secara tegas mengatur kejahatan agresi sebagai bagian dari kejahatan serius yang menjadi perhatian komunitas internasional secara keseluruhan.

\section{METODE PENELITIAN}

Metode penelitian dalam penulisan artikel ini dilakukan berdasarkan pada penelitian yuridis normatif atau penelitian hukum doktrinal dengan spesifikasi deskriptif analitis yang mengedepankan data skunder, primer dan tersier sebagai sumber kajian. Penelitian ini difokuskan pada pengkajian kaidah atau norma hukum yang berkaitan dengan permasalahan yang akan dibahas serta kaitannya terhadap

6 Lita Widyo Hastuti, 'Kontrol Diri Dan Agresi : Tinjauan Meta-Analisis', 26.1 (2018), 42-53 <https://doi.org/10.22146/buletinpsikologi.32805>. 
asas, sistematika serta harmonisasi hukum. ${ }^{7}$

Teknik pengumpulan data yang digunakan dilakukan melalui studi kepustakaan sebagai data sekunder ${ }^{8}$ berupa bahan hukum primer dan bahan hukum sekunder terkait kedudukan tindakan use of force Negara Perancis dalam konflik Republik Mali sebagai suatu kejahatan agresi dan akibat hukum terhadap suatu negara atas tindakan kejahatan agresi yang dilakukannya. Pendekatan yang digunakan dalam penelitian ini adalah:

1) Pendekatan perundang-undangan (statute approach) sebagai bagian dari fokus penelitian berupa Piagam Perserikatan Bangsa Bangsa, Statuta Roma, Konvensi Jenewa 1949, Resolusinya PBB No. 2444 (XXIII) Tahun 1968 Tentang Respect for Human Rights in Armed Conflicts, United Nations General Assembly Resolution 3314 Tahun 1974, Protokol Tambahan I Tahun 1977, Responsibility Of States For Internationally Wrongful Acts 2001 dan International Criminal Court Review Conference Kampala 2010;

2) Pendekatan kasus (case approach) terhadap fokus penelitian berupa inisiatif intervensi Negara Perancis pada konflik Republik Mali Tahun 2012.

\section{PEMBAHASAN DAN ANALISIS}

\subsection{Kedudukan Tindakan Use of Force Negara Perancis Dalam Konflik Republik Mali Sebagai Bagian Dari Kejahatan Agresi}

Perkembangan ilmu pengetahuan dan teknologi pada era moderm seperti saat ini telah sangat mempengaruhi kehidupan bangsa-bangsa didunia. ${ }^{9}$ Sejalan dengan adanya perkembangan tersebut, permasalahan-permasalahan yang kompleks dalam masyarakat internasional juga semakin berkembang pula bentuk dan latar belakangnya. ${ }^{10}$

Non use of force sebagai bagian dari ketentuan asas-asas hukum internasional

\footnotetext{
${ }^{7}$ Lexy J. Moleong, Metode Penelitian Kualitatif (Edisi Revisi) (Bandung: Remaja Rosdakarya, 2017).

8 Soejono Soekanto dan Sri Mamudji, Penelitian Hukum Normatif Suatu Tinjauan Singkat (Jakarta: Raja Grafindo Persada, 2009).

9 Mochtar Kusumaatmadja dan Etty R. Agoes, Pengantar H|ukum Internasional (Bandung: Alumni, 2003).

10 Ade Pratiwi Susanty, 'KEWENANGAN DAERAH DALAM MEMBUAT PERJANJIAN INTERNASIONAL DI INDONESIA', Jurnal Selat, Volume. 5, 2.
} 
sudah seharusnya diketahui dan dilaksanakan oleh setiap negara dalam melakukan hubungan internasional sebagaimana diatur dalam Deklarasi Asas-Asas Hukum Internasional 1947.11 Dalam menjalankan hubungan internasional, setiap negara harus menjauhkan diri dari tindakan mengancam atau menggunakan kekerasan atau cara apapun yang bertentangan dengan tujuan PBB terhadap integritas wilayah atau kemerdekaan politik suatu negara lain. ${ }^{12}$ Akan tetapi seandainya memang tindakan menggunakan kekerasan atau bahkan perang sekalipun harus ditempuh, maka para pihak harus melaksanakannya sesuai dengan hukum humaniter. ${ }^{13}$

Penggunaan kekuatan merupakan karakteristik utama yang menentukan jenis operasi (dalam keadaan konflik) dan otoritas penggunaan kekuatan haruslah jelas dan tertulis didalam mandat. ${ }^{14}$ Kekuatan (force) diartikan sebagai istilah umum yang mengggambarkan penggunaan kekuatan secara fisik untuk mencapai tujuan dan kekuatan yang dimaksud dibagi menjadi dua, yaitu kekuatan tanpa senjata (unarmed force) dan kekuatan dengan senjata (armed force). ${ }^{15}$

Piagam PBB melalui Pasal 51 juga secara tegas telah melarang atau tidak memperbolehkan adanya tindakan yang merugikan hak perseorangan atau bersama untuk membela diri apabila suatu serangan bersenjata terjadi terhadap negara anggota PBB sampai dengan Dewan Keamanan mengambil tindakan-tindakan yang diperlukan untuk memelihara perdamaian dan keamanan internasional. ${ }^{16}$

Setiap tindakan yang diambil oleh negara anggota dalam melaksanakan haknya untuk membela diri harus segera dilaporkan kepada Dewan Keamanan PBB. Namun, Dewan Keamanan pada setiap waktu dapat mengambil tindakan yang dianggap perlu dengan cara yang bagaimanapun untuk memelihara atau memulihkan perdamaian serta keamanan internasional.

Pelaksanaan intervensi yang dilakukan oleh Negara Perancis seharusnya tidak boleh dilakukan dengan menggunakan kekerasan (use of force) terhadap integritas wilayah atau kemerdekaan politik, selain itu Tindakan sebagaimana dimaksud harus berdasarkan izin atau otorisasi Dewan Keamanan PBB atau dilakukan dengan tidak

\footnotetext{
11 Malcolm N. Shaw QC, Hukum Internasional (Bandung: Nusa Media, 2013).

12 Haryomataram, Pengantar Hukum Humaniter (Jakarta: PT. Rajawali Press, 2005).

${ }^{13}$ A Pendahuluan, 'Agresi Israel Terhadap Palestina Perspektif Hukum Humaniter Internasional', 2009, 110-18.

14 Trevor Findlay, The Use Of Force In Peace Operations (Oxford: Oxford university press, 2004).

15 Ibid, hlm. 432.

16 Finahliyah Hasan, 'Analisis Kebijakan Pre-Emptive Self Defence George W. Bush, JR Terhadap Afghanistan', Jurnal Winua Jurusan Hubungan Internasional, Volume 1 N, 98.
} 
melanggar ketentuan-ketentuan dalam Piagam PBB. Dalam melakukan tindakan intervensi, negara harus mendapatkan izin PBB terlebih dahulu melalui Dewan Keamanan PBB yang selanjutnya disebut dengan DK PBB yang berbentuk rekomendasi berisikan pertimbangan-pertimbangan terhadap keadaan yang menjadi alasan pembolehan tindakan intervensi sebagaimana dimaksud dan apakah tindakan intervensi tersebut diperlukan terhadap keadaan-keadaan yang dihadapi. ${ }^{17}$

Pada dasarnya terdapat beberapa kriteria tertentu terkait pembolehan tindakan intervensi yang dinyatakan oleh Centre for Strategic Studies, Victoria University of Wellington diantaranya adalah ketika pemerintahan negara tempat pelanggaran berat HAM terjadi tidak bersedia (unwilling) atau tidak mampu (unable) untuk menghentikan pelanggaran yang dimaksud. Dalam hal ini, Republik Mali pada praktiknya telah berupaya untuk meminta bantuan pada organisasi internasional PBB dalam suratnya. ${ }^{18}$

Selain itu, intervensi kemanusiaan pada dasarnya harus dilaksanakan secara proporsional guna mewujudkan tujuan yang hendak dicapai, sehingga tidak menimbulkan kerusakan atau kerugian yang tidak perlu. Namun pada praktiknya, Perancis telah secara nyata melakukan pelanggaran terhadap ketentuan Konvensi Jenewa atas tewasnya sejumlah korban (5 (lima) warga sipil) dalam serangan udara yang digencarkan Negara Perancis pada intervensi yang dilakukan olehnya dalam konflik Republik Mali.

Setiap tindakan use of force maupun intervensi yang dilakukan berdasarkan otorisasi DK PBB dapat dibenarkan menurut hukum internasional. Tanpa otorisasi Dewan Keamanan tindakan tersebut diangap tidak sah dan bertentangan dengan hukum internasional serta ketentuan-ketentuan piagam PBB. 19

Dalam hal terjadinya agresi, suatu negara dapat dikatakan melakukan tindakan tersebut ketika menggunakan kekuatan bersenjata terhadap kedaulatan, integritas teritorial atau kemerdekaan politik negara lain atau dengan cara lain yang tidak sesuai dengan Piagam PBB. ${ }^{20}$ Dan Negara Perancis atas tindakan intervensi yang dilakukan olehnya dalam hal ini telah mengakibatkan korban jiwa yang digolongkan

\footnotetext{
17 Pasal 39, Pasal 41 dan Pasal 51 Bab VII Piagam PBB

18 'No Title', Http://Www.Euronews.Com/2013/01/11/Mali-Government-Asks-France-for-Military-Aid/.

19 Boer Mauna, Hukum Internasional : Pengertian Peranan Dan Fungsi Dalam Era Dinamika Global (Edisi Kedua) (Bandung: PT. Alumni, 2011).

20 Antonio Cassese, International Criminal Law (New York: Oxford University Press, 2003).
} 
sebagai suatu kejahatan agresi. ${ }^{21}$

International Criminal Court Review Conference Campala 2010 menyatakan bahwa suatu tindakan dapat dinyatakan sebagai act of aggression dengan syarat: ${ }^{22}$

1) Adanya invasi atau serangan oleh angkatan bersenjata dari suatu negara di wilayah negara lain atau pendudukan militer apapun walaupun secara sementara namun memiliki dampak atas invasi atau serangan tersebut atau aneksasi apapun yang dilakukan dengan menggunakan kekerasan terhadap wilayah tersebut atau negara lain atau bagian daripadanya;

2) Pengeboman oleh angkatan bersenjata dari suatu negara terhadap wilayah negara lain atau penggunaan senjata apapun oleh suatu negara terhadap wilayah negara lain;

3) Blokade pelabuhan atau pantai suatu negara oleh angkatan bersenjata negara lain;

4) Suatu serangan oleh angkatan bersenjata suatu negara terhadap pasukan darat, laut atau udara atau armada laut dan udara dari negara lain;

5) Penggunaan angkatan bersenjata dari satu negara yang berada dalam wilayah negara lain dengan persetujuan negara penerima yang bertentangan dengan ketentuan yang ditentukan dalam perjanjian atau perpanjangan kehadiran mereka di wilayah tersebut diluar pengakhiran perjanjian;

6) Tindakan suatu negara yang mengizinkan wilayahnya yang telah ditempatkannya pada bagian negara lain untuk digunakan oleh negara lain tersebut untuk melakukan suatu tindakan agresi terhadap negara ketiga; dan

7) Pengiriman oleh atau atas nama negara terikat, kelompok, laskar bersenjata atau tentara bayaran yang melakukan tindakan angkatan bersenjata terhadap negara lain seperti tindakan yang dinyatakan sebelumnya atau keterlibatan substansial atasnya.

Kejahatan agresi sebagai salah satu kejahatan yang dikenal dalam hukum

21 Pasal 1 United Nations General Assembly Resolution 3314 tentang definisi agresi yang termasuk dalam act of aggression yang merupakan penjelasan lebih jauh dari isi Pasal 2 ayat (4) Piagam PBB. Sedangkan crime of aggression berdasarkan article 8 Bis ayat (1) International Criminal Court Review Conference Kampala 2010

22 Sumaryo Suryokusumo, 'Agresi Dalam Perspektif Hukum Internasional', Jurnal Mimbar Hukum, Volume 3 N, 38. 
pidana internasional tercantum dalam Rome Statute of The International Criminal Court merupakan bagian dari kejahatan internasional dibawah yurisdiksi International Criminal Court. ${ }^{23}$ Deklarasi Universal Hak Asasi Manusia (DUHAM) atau Universal Independent of Human Right 1948 pada Pasal 3 juga menyatakan bahwa setiap orang berhak atas kehidupan, kebebasan dan keselamatan sebagai individu. ${ }^{24}$

Perancis melancarkan serangannya di Republik Mali pada tanggal 11 Januari 2012 sedangkan PBB menyatakan dukungannya terhadap Perancis pada tanggal 14 Januari 2012. Tindakan intervensi pada dasarnya harus dilakukan secara kolektif (bersama). Namun tindakan intervensi militer yang dilakukan Perancis di Republik Mali dalam hal ini dilakukan secara personal (sendirian). Adanya upaya-upaya penyelesaian sengketa secara damai sebagaimana disediakan dalam aturan hukum internasional seperti perundingan, penyelidikan, mediasi, konsiliasi, arbitrase dan lain sebagainya juga tidak diupayakan terlebih dahulu oleh Perancis sebelum mengambil langkah untuk melakukan tindakan intervensi yang dimaksud.

Setiap pasukan militer yang melakukan intervensi diharuskan untuk menaati dan menghormati Konvensi Jenewa dan hukum internasional, namun Perancis pada praktiknya telah melanggar Pasal 51 ayat (4) Protokol Tambahan I Tahun 1977 terkait perlindungan bagi penduduk sipil karena melakukan serangan udara yang menimbulkan kerugian yang tidak perlu berupa jiwa masyarakat sipil atau luka-luka dikalangan masyarakat sipil.

\subsection{Akibat Hukum Terhadap Negara Atas Tindakan Kejahatan Agresi}

Salah satu organisasi internasional yang mempunyai kewenangan untuk menyelesaikan sengketa internasional adalah Perserikatan Bangsa Bangsa. Selain menggunakan penyelesaian sengketa dengan cara-cara damai, PBB juga mempunyai kewenangan untuk mengambil tindakan-tindakan kolektif yang diperlukan untuk menyelesaikan suatu sengketa apabila dampak dari sengketa tersebut dapat mengancam perdamaian dan keamanan internasional. ${ }^{25}$

Kekuasaan yang lebih luas untuk memelihara perdamaian dan keamanan dunia

23 Arie Siswanto, Yurisdiksi Material Mahkamah Pidana Internasional (Jakarta: Ghalia Indonesia, 2005).

24 Ahmad Samawi, Pendidikan Hak Asasi Manusia (Jakarta: Direktorat Jenderal Pendidikan Tinggi Departemen Pendidikan Nasional, 2008).

25 D.J. Harris, Cases and Materials on International Law (London: Sweet and Maxwell Limited, 2004). 
juga diserahkan kepada Dewan Keamanan sebagai badan yang berwenang untuk menyelesaikan kebijakan PBB secara cepat dan tegas. Dewan Keamanan telah dijadikan suatu organ eksekutif yang dilengkapi dengan beberapa kewenangan, terutama dibidang pelaksanaan Bab VII Piagam PBB terkait kewenangan Dewan Keamanan PBB dalam rangka menjaga perdamaian internasional.

Dewan Keamanan juga dapat mengambil semua tindakan yang diperlukan mulai dari pemutusan hubungan hingga penggunaan pasukan bersenjata apabila perdamaian dunia dianggap sudahvterancam. ${ }^{26}$ Bab VII Piagam PBB mengatur mengenai intervensi yang pada hakikatnya merupakan suatu diskresi terhadap isi ketentuan piagam itu sendiri yang mana diantaranya menjadi justifikasi terhadap dua jenis tindakan intervensi yang dikenal dalam Piagam PBB, yaitu intervensi kolektif atas mandat Dewan Keamanan PBB dan intervensi dalam rangka membela diri (self defense).

Dalam rangka menciptakan perdamaian dan keamanan internasional dalam menyelesaikan suatu sengketa, PBB memiliki empat kelompok tindakan yang secara umum dapat dibedakan menjadi: ${ }^{27}$

\section{1) Preventive Diplomacy}

Suatu tindakan untuk mencegah timbulnya suatu sengketa antara para pihak, mencegah meluasnya suatu sengketa atau membatasi perluasan suatu sengketa;

2) Peace Making

Suatu tindakan yang membawa para pihak yang bersengketa untuk saling sepakat, khususnya melalui cara-cara damai. Tujuan PBB dalam hal ini adalah untuk mencegah konflik dan menjaga perdamaian;

\section{3) Peace Keeping}

Suatu tindakan untuk mengerahkan kehadiran PBB dalam memelihara perdamaian dengan kesepakatan para pihak yang berkepentingan;

4) Peace Building

Suatu tindakan mengidentifikasi dan mendukung struktur-struktur yang ada guna memperkuat perdamaian untuk mencegah suatu konflik yang telah

\footnotetext{
26 Imam Mulyana dan Irawati Handayani, 'Peran Organisasi Regional Dalam Pemeliharaan Perdamaian Dan Keamanan Internasional', Jurnal Cita Hukum (FSH UIN Syarif Hidayatullah, Jakarta), Vol. 3 No., 248.

27 Huala Adolf, Hukum Penyelesaian Sengketa Internasional (Jakarta: Sinar Grafika, 2004).
} 
didamaikan berubah kembali menjadi konflik. Peace Building dalam hal ini lahir setelah berlangsungnya konflik.

Dalam rangka mewujudkan tindakan-tindakan sebagaimana dimaksud, PBB diberikan kewenangan sesuai dengan Bab VII Piagam PBB untuk mengambil tindakan-tindakan yang dianggap perlu, termasuk membentuk pasukan internasional apabila penyelesaian sengketa dengan cara-cara damai tidak berhasil.

Pada dasarnya hukum internasional dalam keadaan-keadaan tertentu memberikan hak kepada suatu negara untuk melakukan intervensi terhadap negara lain. Keadaan ini merupakan suatu pengecualian yang dibenarkan, keadaan-keadaan tersebut diantaranya: ${ }^{28}$

1) Intervensi kolektif sebagaimana diatur dalam Piagam PBB;

2) Untuk melindungi hak-hak dan kepentingan negara serta keselamatan jiwa warga negaranya di luar negeri;

3) Sebagai pembelaan diri, jika intervensi diperlukan untuk melenyapkan bahaya serangan bersenjata yang nyata dan mengancam;

4) Dalam menangani urusan sebuah protektorat yang berada di bawah dominionnya;

5) Jika negara yang mengalami intervensi itu telah jelas melakukan pelanggaran terhadap hukum internasional terutama menyangkut negara yang melakukan intervensi.

Pada dasarnya PBB dalam hal ini berwenang memberikan sanksi atas pelanggaran tersebut dan dapat menjatuhkan sanksi administratif berupa penangguhan hak-hak keanggotaan terhadap pelaku penggunaan kekerasan yang menyalahi ketentuan intervensi yang sah menurut piagam PBB.

Dalam konflik Republik Mali, Dewan Keamanan PBB atas kewenangannya pada dasarnya telah melakukan tindakan pencegahan atau tindakan pemaksaan sebelumnya. Embargo dibidang ekonomi pun telah dilakukan guna meminimalisir aktivitas pihak pemberontak dalam transaksi ekonomi. Tentara ECOWAS yang diperintahkan oleh PBB juga dikirim untuk membantu masyarakat sipil yang menjadi korban konflik tersebut.

Akan tetapi terhadap situasi dan kondisi yang bersifat continue, Pasal 6 Piagam

28 J.G. Starke, Pengantar Hukum Internasional (Jakarta: Sinar Grafika, 1988). 
PBB memberikan hak untuk mengeluarkan negara anggota dari organisasi apabila negara tersebut melanggar prinsip Piagam PBB secara terus menerus. Pemecatan anggota PBB ini harus didasari oleh pelanggaran yang berulang-ulang. Berdasarkan pengertian tersebut maka pelanggaran yang hanya dilakukan satu kali meskipun berat, tidak dapat dilakukan pemecatan namun PBB dapat mengambil tindakan lain terhadap pelanggaran yang dilakukan negara yang bersangkutan..$^{29}$

Dalam konflik Republik Mali, tindakan intervensi yang diupayakan Negara Perancis pada dasarnya bertujuan untuk memberikan bantuan kepada pemerintah Republik Mali agar pemerintahan tidak dikuasai pemberontak. Namun pada prosesnya, setelah Perancis melakukan intervensi pada konflik yang terjadi di Republik Mali, permasalahan HAM tidak malah tindak kunjung menurun. Bahkan Badan Amnesti Internasional mengumumkan bahwa terdapat 5 (lima) masyarakat sipil termasuk 3 (tiga) anak-anak diantaranya tewas dalam serangan udara yang digencarkan Negara Perancis di wilayah utara Mali.

Sedangkan pada sisi yang berlainan, Pasal 24 Konvensi Jenewa 1949 mewajibkan pihak-pihak dalam pertikaian untuk mengambil tindakan yang perlu guna menjamin bahwa anak-anak dibawah lima belas tahun, yatim piatu atau yang terpisah dari keluarga sebagai akibat perang tidak terlantar. ${ }^{30}$

Pada kasus lain, Perancis juga pernah terlibat dalam permasalahan HAM pada konflik Rwanda. Pihak Perancis pada saat itu telah membantu suku Hutu sebagai kelompok militan selaku pihak pembantai. Perancis menembaki siapapun yang mendukung keputusan presiden terdahulu atau musuh dari suku Hutu. Oleh karenanya, pelanggaran HAM yang dilakukan oleh Perancis pada saat itu pada dasarnya dapat diadili oleh Mahkamah Internasional atau ICJ (international Court of Justice).

Pada Tahun 1949 Komite Internasional Palang Merah telah menyusun Konvensi Jenewa ke IV tentang perlindungan bagi orang-orang sipil dalam masa perang. ${ }^{31}$ Selanjutnya Konferensi Internasional Palang Merah ke XX di Wina (Austria) pada tahun 1965 telah berhasil menyusun Resolusi ke XXVIII yang menghimbau semua

\footnotetext{
${ }^{29}$ Novrizal Aji, 'Kewenangan Uni Eropa Dalam Penyelesaian Konflik Di Negara Yang Bukan Anggotanya Menurut Hukum Internasional' (Unversitas Padjadjaran, 2012).

${ }^{30}$ Hukum Internasional (Yogyakarta: Penerbit Andi Offset).

${ }^{31}$ Arlina Permanasari Dkk, Pengantar Hukum Humaniter (Jakarta: ICRC, 1999).
} 
pemerintah dan penguasa yang bertanggung jawab dalam sengketa bersenjata untuk menerapkan asas-asas tertentu. Resolusi ini kemudian diperkuat oleh PBB dengan Resolusinya No. 2444 (XXIII) tahun 1968 tentang Respect for Human Rights in Armed Conflicts dengan isi yang sama. ${ }^{32}$

Apabila Dewan Keamanan PBB telah menentukan bahwa suatu negara telah dengan nyata melakukan ancaman atau pelanggaran perdamaian atau tindakan agresi maka Dewan Keamanan dapat mengambil langkah-langkah berupa sanksi ekonomi tanpa menggunakan kekuatan senjata agar keputusan Dewan dapat ditaati. Namun apabila langkah tersebut dirasa tidak cukup, maka Dewan Keamanan dapat menjatuhkan saksi militer dengan mengambil tindakan melalui kekuatan darat, laut atau udara. ${ }^{33}$

Sebagai bagian dari yurisdiksi International Criminal Court, pelaku kejahatan agresi dalam hal ini diancam dengan sejumlah sanksi pidana. ${ }^{34}$ Pasal 51 Konvensi Jenewa 1949 menyatakan bahwa pihak peserta agung tidak diperkenankan membebaskan dirinya atau pihak peserta agung lain dari tanggung jawab apapun yang disebabkan olehnya sendiri atau oleh pihak peserta agung lainnya berkenaan dengan pelanggaran-pelanggaran yang termaksud dalam pasal yang terdahulu. ${ }^{35}$

Pada dasarnya Pasal 51 Konvensi Jenewa 1949 bertujuan untuk mencegah pihak yang kalah melepaskan haknya dalam perjanjian perletakan senjata untuk menuntut pengusutan atau penuntutan terhadap orang-orang yang melanggar konvensi dari pihak yang menang atau menuntut ganti kerugian yang disebabkan oleh pelanggaran berat yang dilakukan anggota angkatan bersenjata pihak lawan. ${ }^{36}$ Maksud dari ketentuan ini adalah untuk memperkuat dan menegaskan kewajibankewajiban sebagaimana diatur dalam Pasal 49 Konvensi Jenewa Tahun 1949 untuk memberantas penyalahgunaan yang terjadi dan menghukum para pelanggar. ${ }^{37}$

Apabila salah satu anggota yang berkonflik melanggar ketentuan konvensi atau protokol tersebut, maka negara anggota wajib bertanggung jawab untuk membayar

\footnotetext{
32 Syamin A.K, Hukum Internasional Humaniter (Jilid 1) (Bandung: Armico, 1985).

33 Maryam Az Zahra, 'Tinjauan Hukum Internasional Terhadap Penggunaan Kekuatan Bersenjata (Studi Kasus Intervensi Militer Rusia Di Wilyah Ossetia Selatan)' (Universitas Indonesia, 2012).

34 Thalis Noor, 'Agresi Dan Kejahatan Terhadap Perdamaian', Jurnal Supremasi Hukum, Vol. 3, No, 36.

35 Jawahir Thontowi dan Pranoto Iskandar, Op. Cit, hlm. 189.

36 Mochtar Kusumaatmadja, Konvensi-Konvensi Djenewa Tahun 1949 Mengenai Perlindungan Korban Perang (Bandung: Binatjipta, 1968).

37 Syamin A.K, Op.Cit, hlm. 105.
} 
kompensasi. Tanggung jawab ini dapat dikenakan atas semua tindakan yang dilakukan oleh orang-orang yang menjadi bagian dari angkatan bersenjata. Suatu Negara yang bertanggung jawab atas tindakan yang salah secara internasional berkewajiban untuk melakukan restitusi guna membangun kembali situasi yang ada sebelum tindakan salah tersebut dilakukan, restitusi dapat diberikan sejauh:

a. Tidak mustahil secara material;

b. Tidak melibatkan beban dari semua proporsi untuk manfaat yang berasal dari restitusi bukan kompensasi.

Namun apabila restitusi tidak dapat diupayakan, negara yang bertanggungjawab atas tindakan tersebut berkewajiban untuk memberikan kompensasi terhadap kerusakan yang disebabkannya. Hal tersebut telah secara tegas diatur dalam Article 35 dan 36 Responsibility Of States For Internationally Wrongful Acts 2001.

Negara yang bertanggung jawab atas tindakan yang salah secara internasional berkewajiban untuk memberikan kepuasan atas cedera yang disebabkan oleh tindakan yang dilakukan olehnya. Kepuasan sebagaimana dimaksud dapat berupa pengakuan pelanggaran, ekspresi penyesalan, permintaan maaf formal atau modalitas lain yang sesuai namun harus proporsional dengan internationally wrongful acts yang diderita negara dan memungkinkan untuk tidak mengambil bentuk pertanggungjawaban yang dianggap dapat menghina atau mempermalukan negara yang bertanggung jawab.

\section{KESIMPULAN}

Pada dasarnya tindakan Perancis telah memenuhi syarat suatu kejahatan agresi berdasarkan Pasal 1 United Nations General Assembly Resolution 3314 tentang definisi agresi atas tindakan penggunaan kekuatan bersenjata yang dilakukan olehnya terhadap kemerdekaan politik dalam negeri Republik Mali. Kesalahan yang dilakukan Negara Perancis dalam hal ini dapat terlihat dari tindakan intervensi yang dilakukan dengan menggunakan kekerasan (use of force) tanpa adanya otorisasi Dewan Keamanan PBB yang mengakibatkan timbulnya korban jiwa.

Tindakan intervensi yang diupayakan oleh Negara Perancis tidak dilakukan 
secara kolektif dan tanpa adanya upaya penyelesaian sengketa secara damai sebelumnya sebagaimana diatur dalam aturan hukum internasional yang sudah sehrusnya diupayakan terlebih dahulu. Bahkan pasukan militer yang tergabung dalam pelaksanaan tindakan tersebut tidak menaati dan menghormati Konvensi Jenewa serta hukum internasional dalam penyelenggaraan tindakan intervensi.

Intervensi kemanusiaan yang diupayakan Negara Perancis pada praktiknya tidak dilaksanakan secara proporsional dengan tujuan yang hendak dicapai. Tindakan penggunaan kekerasan (use of force) yang dilakukan oleh Negara Perancid dalam hal ini menimbulkan kerusakan atau kerugian yang tidak perlu.

Setiap negara yang melakukan pelanggaran terhadap internationally wrongful acts dalam tataran hukum pidana internasional dapat dikenakan sanksi berupa penangguhan hak-hak keanggotaan berdasarkan Pasal 5 Piagam PBB, hal ini dikarenakan dalam kasus intervensi Negara Perancis, Dewan Keamanan PBB telah terlebih dahulu melakukan tindakan pencegahan.

Selain itu, tindakan Perancis dalam melakukan serangan udara yang menyebabkan setidaknya 5 (lima) warga sipil tewas termasuk 3 (tiga) anak diantaranya telah melanggar Pasal 24 Konvensi Jenewa 1949. Sehingga menurut Pasal 51 Konvensi Jenewa jo. Pasal 91 Protokol Tambahan I 1977, Perancis dalam hal ini wajib memberikan ganti rugi pada korban (selain menghukum pilot yang melakukan serangan udara).

Berdasarkan Responsibility Of States For Internationally Wrongful Acts 2001, Negara Perancis dapat diwajibkan untuk mengganti kerugian dalam bentuk restitusi maupun kompensasi terhadap Republik Mali atas tindakan use of force yang telah menyebabkan timbulnya korban jiwa yang digolongkan sebagai kejahatan agresi. Namun apabila restitusi dan kompensasi tidak dapat diupayakan, maka ganti kerugian sebagaimana dimaksud dapat diberikan dalam bentuk kepuasan lainnya yang proporsional dengan internationally wrongful acts yang diderita Republik Mali seperti pengakuan pelanggaran, ekspresi penyesalan maupun permintaan maaf formal, akan tetapi bukan merupakan bentuk pertanggungjawaban yang dianggap dapat menghina atau mempermalukan negara yang bertanggung jawab. 


\section{DAFTAR PUSTAKA}

A.K, Syamin, Hukum Internasional Humaniter (Jilid 1) (Bandung: Armico, 1985)

Adolf, Huala, Hukum Penyelesaian Sengketa Internasional (Jakarta: Sinar Grafika, 2004)

Agoes, Mochtar Kusumaatmadja dan Etty R., Pengantar Hukum Internasional (Bandung: Alumni, 2003)

Aji, Novrizal, 'Kewenangan Uni Eropa Dalam Penyelesaian Konflik Di Negara Yang Bukan Anggotanya Menurut Hukum Internasional' (Unversitas Padjadjaran, 2012)

Cassese, Antonio, International Criminal Law (New York: Oxford University Press, 2003)

Dkk, Arlina Permanasari, Pengantar Hukum Humaniter (Jakarta: ICRC, 1999)

Findlay, Trevor, The Use Of Force In Peace Operations (Oxford: Oxford university press, 2004)

Handayani, Imam Mulyana dan Irawati, 'Peran Organisasi Regional Dalam Pemeliharaan Perdamaian Dan Keamanan Internasional', Jurnal Cita Hukum (FSH UIN Syarif Hidayatullah, Jakarta), Vol. 3 No., 248

Harris, D.J., Cases and Materials on International Law (London: Sweet and Maxwell Limited, 2004)

Haryomataram, Pengantar Hukum Humaniter (Jakarta: PT. Rajawali Press, 2005)

Hasan, Finahliyah, 'Analisis Kebijakan Pre-Emptive Self Defence George W. Bush, JR Terhadap Afghanistan', Jurnal Winua Jurusan Hubungan Internasional, Volume 1 N, 98

Hastuti, Lita Widyo, 'Kontrol Diri Dan Agresi : Tinjauan Meta-Analisis', 26.1 (2018), 42-53 <https://doi.org/10.22146/buletinpsikologi.32805>

Hukum Internasional (Yogyakarta: Penerbit Andi Offset)

Iskandar, Jawahir Thontowi dan Pranoto, Hukum Internasional Kontemporer (Bandung: PT. Refika Aditama, 2006)

Kusumaatmadja, Mochtar, Konvensi-Konvensi Djenewa Tahun 1949 Mengenai Perlindungan Korban Perang (Bandung: Binatjipta, 1968)

Makalew, Alfandrio Christian Putra, 'Kedudukan Pre-Emptive Strike (Serangan Pendahuluan) Dalam Hukum Internasional', Jurnal Lex Et Societatis, Vol. VII N.Mei 2019, 13

Malang, Universitas Negeri, 'Aktor Non-Negara Dalam Hubungan Internasional', 5

Mamudji, Soejono Soekanto dan Sri, Penelitian Hukum Normatif Suatu Tinjauan Singkat (Jakarta: Raja Grafindo Persada, 2009)

Mauna, Boer, Hukum Internasional: Pengertian Peranan Dan Fungsi Dalam Era Dinamika Global (Edisi Kedua) (Bandung: PT. Alumni, 2011) 
Moleong, Lexy J., Metode Penelitian Kualitatif (Edisi Revisi) (Bandung: Remaja Rosdakarya, 2017)

'No Title', Http://Www.Euronews.Com/2013/01/11/Mali-Government-Asks-Francefor-Military-Aid/

Noor, Thalis, 'Agresi Dan Kejahatan Terhadap Perdamaian', Jurnal Supremasi Hukum, Vol. 3, No, 36

Pendahuluan, A, 'Agresi Israel Terhadap Palestina Perspektif Hukum Humaniter Internasional', 2009, 110-18

Perwita, A.A.B. \& Yani, Y.M., Pengantar Ilmu Hubungan Internasional (Bandung: Rosda, 2006)

QC, Malcolm N. Shaw, Hukum Internasional (Bandung: Nusa Media, 2013)

Samawi, Ahmad, Pendidikan Hak Asasi Manusia (Jakarta: Direktorat Jenderal Pendidikan Tinggi Departemen Pendidikan Nasional, 2008)

Sefriani, Hukum Internasional (Edisi Pertama) (Jakarta: Rajawali Pers, 2010)

Siswanto, Arie, Yurisdiksi Material Mahkamah Pidana Internasional (Jakarta: Ghalia Indonesia, 2005)

Starke, J.G., Pengantar Hukum Internasional (Jakarta: Sinar Grafika, 1988)

Suryokusumo, Sumaryo, 'Agresi Dalam Perspektif Hukum Internasional', Jurnal Mimbar Hukum, Volume 3 N, 38

Susanty, Ade Pratiwi, 'KEWENANGAN DAERAH DALAM MEMBUAT PERJANJIAN INTERNASIONAL DI INDONESIA', Jurnal Selat, Volume. 5, 2

Zahra, Maryam Az, 'Tinjauan Hukum Internasional Terhadap Penggunaan Kekuatan Bersenjata (Studi Kasus Intervensi Militer Rusia Di Wilyah Ossetia Selatan)' (Universitas Indonesia, 2012) 